\title{
Test Equipment Adding Electric Supercharger on Injection Machine for Biofuel Optimization
}

\author{
Mahrus Khoirul Umami ${ }^{*}$, Rullie Annisa, Faikul Umam, Hairil Budiarto, Ibnu Irawan \\ Mechanical Engineering Department, University of Trunojoyo Madura, Indonesia
}

\begin{abstract}
One of the problems that occur in our earth is air pollution and the depletion of fossil fuel stocks. Researchers want to make research on how the fuel burns completely, so that the resulting exhaust gas is environmentally friendly. In addition, this research is expected as an education and comparison before and after the turbofan is given. This study will control the AFR (Air Fuel Ratio) in the intake air to get the right ratio of fuel to air stoichiometry. By controlling the air intake into the engine and adding a turbofan using the PID method. The way the turbofan works is using the lamba sensor as system input, then the value of the lamba sensor is entered into the PID method. From the PID value will determine the speed of the brushless motor which aims to get the best AFR. By looking at the lambda sensor output which is close to the setpoint of 0.5 , it is expected to produce a more perfect mixture of air and gasoline.
\end{abstract}

Keywords: Biofuel, Air Fuel Ratio, PID method

\section{Introduction}

Urban areas are the main cause of air pollution, because too many vehicles also cause congestion everywhere and make pollution worse. In addition, conventional engines are currently still not able to make complete combustion, which results in releasing more gases that are not environmentally friendly.

In making combustion perfect, it is necessary to adjust the AFR or air fuel ratio, by providing air and fuel with a stoichiometric mixture, where 1 kilo of fuel requires 14.7 kilos of air [3], but in previous studies the mixture in the engine could not get a mixture. perfect, the results of previous studies always get a rich mixture or a mixture whose ratio is more fuel than air

To get the perfect mixture, it is necessary to add an auxiliary tool to supply air into the combustion chamber, which is usually found in a car or motorcycle with a large CC (Centimeter Cubic) engine capacity, and a turbo tool which is used to supply air into the engine. But what about small engine motors, can it be done? Therefore, a pressurized air enhancer is made that can be used by a motor with a small engine which can be called a supercharger.

The way the tool works is to use a brushless motor connected to a fan which is used to supply air into the combustion chamber. Arduino is used for control by using the output data from the lambda sensor to determine how fast the brushless motor rotates the fan to supply air, with the condition that if the lambda sensor detects a rich mixture, the brushless motor will spin faster, on the contrary if the lambda sensor detects a poor mixture, the brushless motor rotates. slows down, so depends on the output of the lambda sensor until the mix is perfect.

\section{Literature Review}

This previous researcher has become one of the references for research in conducting research so that researchers can enrich the concepts used in reviewing the research carried out. There are many studies on AFR, including experimental studies on the effect of adding combustion air to the performance and exhaust gas emissions of the Honda CB150R engine fueled by bioethanolne100. One classic example of the importance of AFR, where a blower is placed in front of the motor to increase the supply of air to the combustion engine [4]. In contrast to this final project which has a plug and play design into the air intake of the injection motor.

There are many methods used in AFR research. One of them is a journal entitled the design of an air fuel ratio (AFR) controller based on adaptive PID on a 4 stroke gasoline engine. A reference was obtained regarding the design of the AFR setting using the PID method which controls the amount of gasoline that will enter the combustion chamber so that the AFR is in complete combustion or stoichiometry [5]. But in this study, it is different from this final project, namely in the AFR setting which regulates the use of a brushless motor as a supplier of air entering the combustion chamber so that

\footnotetext{
* Corresponding author : mahrus.umami@trunojoyo.ac.id
} 
it is perfect, and using the PID method so that the rotation of the brushless motor is more perfect.

\section{Methods}

Block Diagram on the supercharger control system using Arduino as the process control system. By adding a PID controller method that is inserted into the microcontroller. This system uses a close loop control system, to minimize errors and make the system approach the specified output. Lambda sensor as result reading. There is an actuator in the form of a brushless motor for action, and is equipped with an ESC to control the speed of the turbofan. The block diagram can be seen in Figure 3.1

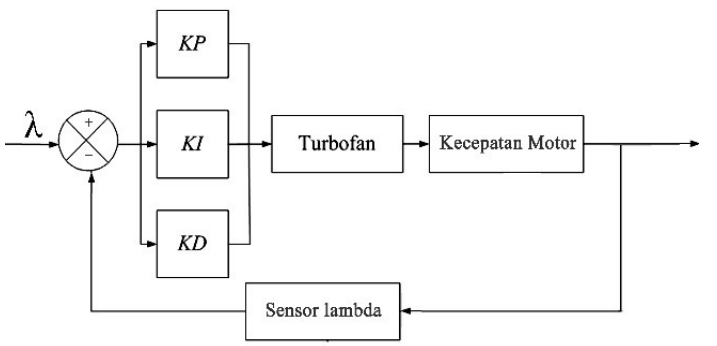

Fig.1. Supercharger block diagram

The mechanical design of the turbofan has dimensions of $8 \times 8 \times 20 \mathrm{~cm}$, which can be seen in Figure 2.

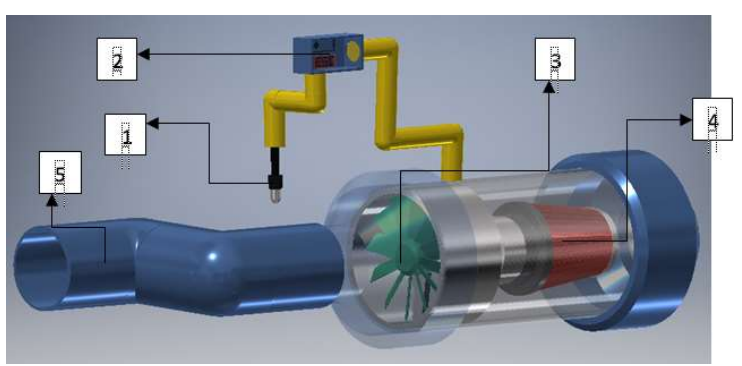

Fig.2. Tool parts

The description of the parts of the tool design in Figure 2 is as follows:

1. Box controller

2. Lambda sensor

3. Fan

4. Air filter

5. intake air connection

Electronic design is an electronic circuit contained in the arrangement by combining several components into an electronic circuit. Basically, electronic design is important in making this final project, because it can affect the automation process of the system to be made. The electronic circuit of the system consists of 1 battery/battery, arduino nano microcontroller, lambda sensor input, and brushless motor output, LCD, and ESC as a motor controller. The use of arduino nano is sufficient for the port requirements in this study. Making a turbofan circuit design whose electronic circuit diagram is shown in Figure 3.

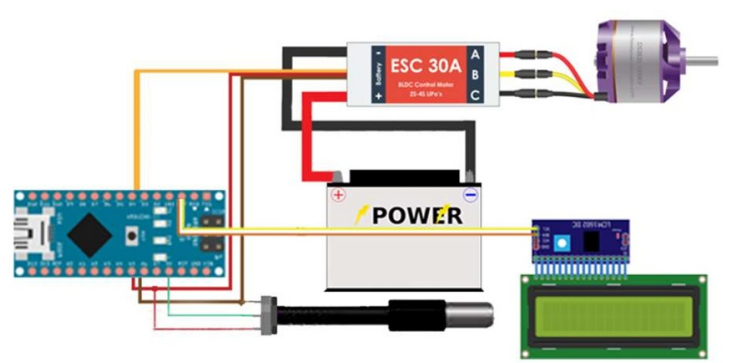

Fig.3. Electronic component design

\section{Result}

In making an engine stand equipped with a supercharger, component selection is very important to facilitate the system in carrying out the detection process. Table 1. is a specification of each component used in the engine stand supercharger.

Table 1. Component Specification

\begin{tabular}{|c|c|c|}
\hline No. & Component & Information \\
\hline 1. & Arduino & Nano \\
\hline 2. & Lambda Sensor & $0-1 \mathrm{~V}$ \\
\hline 3. & Brushless Motor & 16 MegaPixel \\
\hline 4. & Stepdown & $3 \mathrm{~V}$ \\
\hline 5. & LCD & LCD OLED \\
\hline 6. & Battery & $12 \mathrm{~V}$ A \\
\hline 7. & Engine & Beat Fi engine \\
\hline 8. & ESC & $30 \mathrm{~A}$ \\
\hline
\end{tabular}

\subsection{Lambda Sensor Testing}

Here are some program snippets to access the lambda sensor:

void Read_Lamda( $)\{$

int sampling $=100$;

for (int $\mathrm{x}=0 ; \mathrm{x}<$ sampling; $\mathrm{x}++$ )

$\mathrm{val}=\mathrm{val}+$ analogRead(potpin);

$\mathrm{val}=\mathrm{val} /$ sampling;

$\mathrm{val}=\operatorname{map}(\mathrm{val}, 0,1023,90,75)$;

for (int $\mathrm{x}=0 ; \mathrm{x}<$ sampling; $\mathrm{x}++$ )

Lamda $=$ Lamda + analogRead(Pin_Lamda);

Lamda $=$ Lamda/sampling;

Lamda $=$ Lamda $* 0.0048828125$;

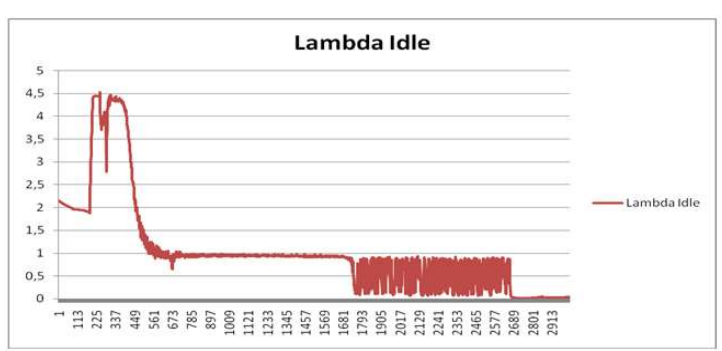

Fig.4. Lambda sensor at Idle 


\subsection{Brushless Motor Test}

Here are some program snippets to access the motor on an electric supercharger.

void Motor()

float Lamda Set $=$ Lamda $* 10$

if (Lamda_Set $<4||$ Lamda_Set $>6$ ) $\{$ //hold speed edf if (Lamda_Set $<4$ ) //add speed edf / rich fuel / air less pos=pos-1;

if (Lamda_Set>6) //reduce speed edf / reduce fuel / air rich

pos $=$ pos +1 ;

if $(\operatorname{pos}>90)$

pos $=90$;

if $(\operatorname{pos}<75)$

pos $=75$;

Motor Speed

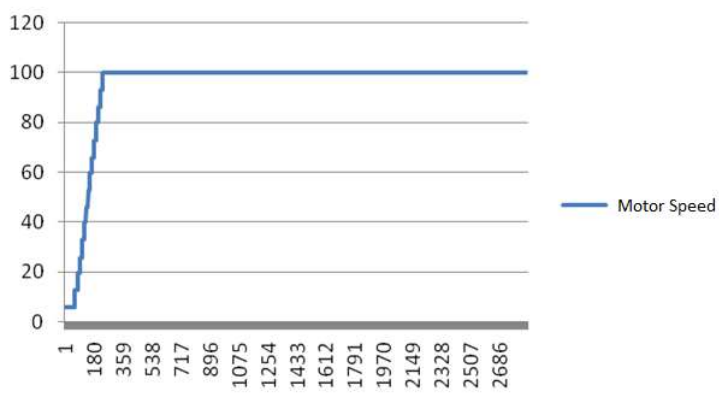

Fig.5. Brushless Speed Motor

\subsection{Lambda sensor test with electric Turbofan output}

In this test the output value from the lambda sensor is directly executed with the motor speed. Figure 6 . below shows that the speed of the motor affects the value of the lambda sensor, even though the speed of the motor is not stable. From the graph, the lambda sensor in the 300 second position shows that the lambda sensor starts to stabilize to a value of 0.5 . This is different from Figure 4. which shows the lambda sensor starting to stabilize at 1300 seconds. Likewise, Figure 7 shows the unstable motor speed. Therefore we need a method to further stabilize the motor speed.

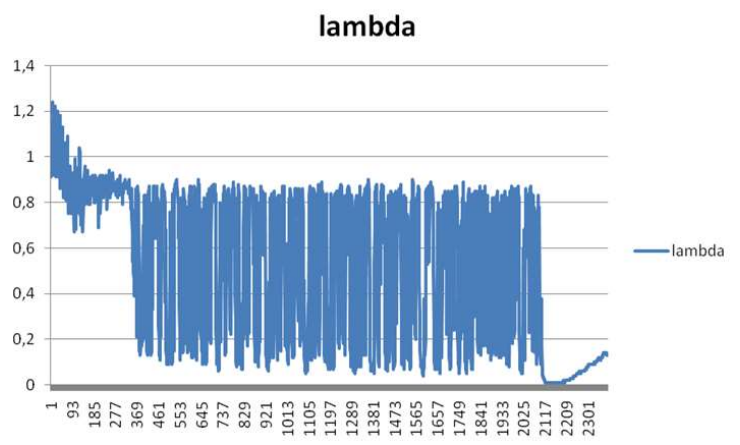

Fig. 6. Lambda sensor value when using a supercharger

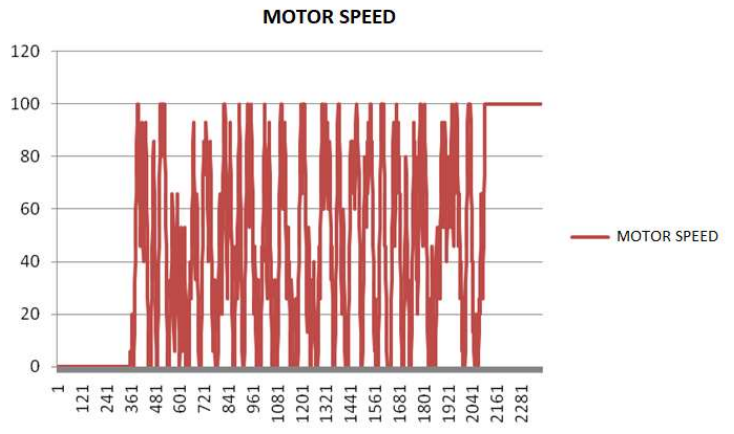

Fig. 7. Motor speed when given value from lambda sensor

\section{5 conclusion}

In the experiment of a compressed air booster with a supercharger, using this gasoline-fueled injection motor, it can be proven that the use of an air booster has a significant effect on complete combustion. the use of intelligent control that utilizes lambda sensor technology gives the effect of providing fuel and air to become stoichiometric.

\section{References}

[1] Ismiyati, Marlita, D., Saidah, D. " Pencemaran Udara Akibat Emisi Gas Buang Kendaraan Bermotor". Universitas Muhammadiyah Jakarta, (2014).

[2] Perkembangan Jumlah Kendaraan Bermotor Menurut Jenis, 1949-2018 https://www.bps.go.id/linkTableDinamis/view iid/1133 diakses 1 April 2020.

[3] Sutiman : " Perbandingan AFR dengan Kondisi Mesin" Jurusan Otomotif Fakultas. Teknik Universitas Negeri Yogyakarta. Yogyakarta, (2005).

[4] Fikri, Naziful. ”Studi Eksperimental Pengaruh Penambahan Udara Pembakaran Terhadap Unjuk Kerja Dan Emisi Gas Buang Engine Honda Cb150r Berbahan Bakar Bioethanol E100“. Jurusan Teknik Mesin, Fakultas Teknologi Industri, Institut Teknologi Sepeluh Nopember, (2017).

[5] Pinunjul D. A., Wahyudi, Sudjadi. " Perancanaan Air Fuel Ratio (AFR) Controller Berbasis PID Adptif Pada Mesin Bensin 4 Langkah “. Departemen Teknik Elektro Engineering, Universitas Diponogoro, Semarang, Indonesia, (2018).

[6] Paryono. "Sensor Lambda Sebagai Pengatur Untuk Mengurangi Komponen Gas Buang Beracun Pada Kendaraan Bermotor “. Jurusan Pendidikan Teknik Mesin,

Fakultas Pendidikan Teknologi dan Kejuruan, IKIP, Malang, Indonesia, (2000).

[7] Hamann, E., Manger, H., \& Steinke, L. " Lambdasensor with Y2O3-Stabilized $\mathrm{ZrO2-}$ ceramic for application in automotive emission control systems “. (No. 770401). SAE Technical Paper, (1977). 
[8] Dermawan Q., Sadli M., Bintoro A. (2018). " Penggunaan Motor Dc Brushless Sunny Sky X2212-13 Kv : 980 Ii Pada Perancangan Quadcopter “. Jurusan Teknik Elektro, Fakultas Teknik, Universitas Malikussaleh.

[9] Dr. Junaidi, S.Si., M. Sc, Prabowo Y. D. (2018). " Project Sistem Kendali Elektronik Berbasis Arduino “. ISBN: 978-602-5636-46-2

[10] Araventa S. D. Pengendalian Kecepatan Putar (RPM) Motor DC dengan Metode PID Berbasis Mikrokontroller AtMega328 menggunakan Bahasa Pemrograman Code Vision AVR. Jurnal Ilmiah. D3 Fisika, Universitas Sumatera Utara, (2017).

[11] Akhmad I., Isnawaty, Saputra R. A. JuliDesember (2017). Implementasi Sistem Navigasi Dengan Metode Proportional Integral Derivative (PID) Pada Robot Wall Follower.SemanTIK. ISSN: 2502-8928. 3,2: 912.

[12] Roedy K., Wahyunggoro O., Nugroho P. 2015. Sistem Kendali Kecepatan Motor BLDC Menggunakan Algoritma Hybrid PID Fuzzy.University Research Colloquium. ISSN 2407-9189, 116-124, (2015).

[13] Hari S. Juli 2015. Panduan Praktis Arduino Untuk Pemula.Penerbit: www.elangsakti.com

[14] Pengertian kontrol kecepatan elektronik atau ESC pada motor brushless, (2020)

https://en.m.wikipedia.org/wiki/Electronic_sp eed_control diakses, 5 mei 2020.

[14] Syaibani I. "Analisis Sistem Efi (Electronic Fuel Injection) Pada Sepeda Motor Honda Beat Pgm-Fi”. Program D3 Teknik Mesin Otomotif Dan Manufaktur, Universitas Muhammadiyah Yogyakarta, (2017). 